\title{
PKD1L2 wt Allele
}

National Cancer Institute

\section{Source}

National Cancer Institute. PKD1L2 wt Allele. NCI Thesaurus. Code C150296.

Human PKD1L2 wild-type allele is located in the vicinity of 16q23.2 and is approximately $119 \mathrm{~kb}$ in length. This allele, which encodes polycystic kidney disease protein 1-like 2, may be involved in $\mathrm{G}$ protein-coupled receptor signaling and the regulation of calcium transport. 